\title{
EVALUATION OF THE TRANSPIRATION CHARACTER OF JUNIPERUS MACROCARPA AS AN INVASIVE SPECIES IN WESTERN CRETE, GREECE
}

\author{
ELHAG, M. ${ }^{*}$ - BAHRAWI, J. \\ Department of Hydrology and Water Resources Management, Faculty of Meteorology, \\ Environment \& Arid Land Agriculture, King Abdulaziz University \\ Jeddah 21589, Kingdom of Saudi Arabia \\ *Corresponding author \\ e-mail:melhag@kau.edu.sa \\ (Received $20^{\text {th }}$ Nov 2017; accepted $20^{\text {th }}$ Feb 2018)
}

\begin{abstract}
This study aimed at determining the transpiration characters of Juniperus macrocarpa in a close to 40-year-old even-aged stand categorized into three classes based on canopy size, over a two-year period (2011-2012). The site is located in Palaiochora, $77 \mathrm{~km}$ south of Chania, on the southwest coast of Crete. Sap flow techniques (Granier-type) were used to determine water use. Annual trends in sap flow were generally bell-shaped, and varying significantly between seasons and canopy classes. Winter sap flow was minimal but trees were active when temperatures were above freezing point and trees depended on deep water (below $60 \mathrm{~cm}$ ) for transpiration. Rates increased from $1.46 \mathrm{Ld}^{-1}$ in winter to $3.32 \mathrm{Ld}^{-1}$ in the spring, irrespective of tree canopy class, because of improvement in weather conditions. Maximum transpiration rates were observed during the growing season with an average of $134.42 \mathrm{Ld}^{-1}$ for dominant trees and $8.68 \mathrm{Ld}^{-1}$ for suppressed ones. The daily variations in photosynthetically active radiation, vapor pressure deficit, air temperature, and surface soil water were the principal drivers for transpiration during the growing season. The findings have shown that climate in Crete does not limit the expansion of $J$. macrocarpa and that this expansion will have potentially significant impacts on the ecohydrology of the system.
\end{abstract}

Keywords: Juniperus macrocarpa, sap flow, semi-arid ecosystems, soil water content, transpiration rates

\section{Introduction}

Invasive woody species encroachment into semi-arid grasslands has been attributed to the introduction of livestock, fire suppression (Van Auken, 2000), changes in climate (Reich et al., 2001), increases in atmospheric $\mathrm{CO}_{2}$ concentration (Bradley and Fleishman, 2008) landscape fragmentation (Briggs et al., 2007), reduction in wood harvest rates by native Americans (Fredrickson et al., 2006), dispersal by humans and birds, and natural expansion of the species (Van Haverbeke and Read, 1976). Generally, Junipers are widely distributed across the northern Mediterranean region, some taxa's are grown natively and few are considered to be invasive to the designated study area (Farjon, 2005; Adams, 2014).

Juniperus macrocarpa as an evergreen coniferous species has a predominantly large potential for accommodating precipitation. This is due to the evergreen nature of the species, the relatively large surface leaf area, and considerable intrusion by the understory litters. Water losses estimation from the collective intrusion of juniper canopies and underlying litter layers may reach 70 to $80 \%$ depending on the species and site conditions (Thurow and Hester, 1997). Owens et al. (2006) reported that $47 \%$ of precipitation intrusion by the Ashe juniper (Juniperus ashei) canopy and understory litters. The authors estimated that for a densely covered Ashe juniper forest, closely to 
$250 \mathrm{~mm}$ precipitation would be intervened annually. Owens and Ansley (1997) resolved that the potential transpiration rate of a mature Ashe juniper may reach to $125 \mathrm{~L}$ of water per day, which would be equivalent to 300 to $450 \mathrm{~mm}$ water annually on a landscape scale, depending on the forest dense cover (Elhag and Bahrawi, 2017a).

Other studies on water use by Juniperus species have shown that stand level transpiration rates range from 0.23 to $1.13 \mathrm{~mm} \mathrm{day}^{-1}$ in Utah juniper (Juniperus osteosperma) in Arizona and New Mexico, $1.21 \mathrm{~mm}$ in alligator juniper ( $J$. daydeppeana) in Arizona, and $1.90 \mathrm{~mm} \mathrm{day}^{-1}$ in Ashe juniper (J. ashei) in Texas. These comparatively low transpiration rates reflect juniper's conservative water use which allows it to survive in dry areas (Heilman et al., 2009).

Although several studies have examined the water use in Juniperus species, very few have been conducted on J. macrocarpa especially in semi-arid plains (Van Auken and Mckinley, 2008), where soil water has been testified to be the key limiting factor for plant growth (Chaves et al., 2003; Duursma et al., 2008). Meanwhile, the relative grasses and woody species abundance in semi-arid ecosystems determines the vegetation type (Darrouzet-Nardi et al., 2006; Bradley and Fleishman, 2008).

Moreover, scenarios of future climate change predict increasing air temperatures with increases in water vapor pressure deficits (VPD) experienced by plants (Harmsen et al., 2009). The frequency, intensity, timing, and distribution of precipitation will also be altered (Stocker, 2014). Such vicissitudes will influence vegetation function (especially water vapor flux) and will alter the consequences of the climate and vegetation interaction. Consequently, it is imperative to comprehend the means underlying the plant function and climate interactions in term of efficient water resources management and vegetation (Porporato et al., 2004; Elhag and Bahrawi, 2016).

The heat dissipation method (Granier, 1987) which is designed to measure tree sap flow is the most frequently utilized practices in ecophysiological and forest hydrological studies for whole-tree water use in xylem sap flow determination due to its plainness, a high degree of precision and consistency (Lu et al., 2000).

The adopted technique is based on two probes. The first probe is the heated probe and the second is the reference probe made of stainless steel needle. The basic principle of the two probes is to sense the temperature difference generated between the two thermo-couple copper wired probes. Therefore, both probes are literally implanted into the stem 10-15 cm apart from each other (Granier, 1987; Lu et al., 2000).

The current research hypothesis assumes that is that Juniperus macrocarpa is responsible for the shifts of the groundwater content in the study area. Therefore, Juniper transpiration rates are subjected for comprehensive investigation in the designated study area. The goal of the study is to estimate the whole-tree water use in term of transpiration of the woody species Juniperus macrocarpa in semi-arid ecosystems of western Crete and the transpiration rate significances on the water balance, soil water availability, and consequently groundwater recharge in the ecosystem.

\section{Materials and methods}

\section{Study species}

Juniperus macrocarpa is a dispersal shrub up to $6 \mathrm{~m}$ height; once in a while it may reaches up to $15 \mathrm{~m}$ height. Leaves are lanceolate in principle up to $20 \mathrm{~mm}$ long and up 
to $4 \mathrm{~mm}$ wide. The stomatal structure is a dual band split by a midrib on the inward surface (Farjon, 2005). The seeds are berry-like in cones forms with a waxy covering and usually scattered (Adams, 2014). The dust cones are yellow, reaches to $3 \mathrm{~mm}$ long, and shedding off its duct shortly after winter (Muñoz-Reinoso, 2004).

\section{Study area}

The study area located in the South West of Crete and covers an area of about 4317.21 ha, $35^{\circ} 25^{\prime} 51^{\prime \prime} \mathrm{N}$ and $35^{\circ} 09^{\prime} 47^{\prime \prime} \mathrm{N}$ latitudes, $24^{\circ} 32^{\prime} 07^{\prime \prime} \mathrm{E}$ and $24^{\circ} 54^{\prime} 42^{\prime \prime} \mathrm{E}$ longitudes (Fig. 1). The recognized stand history and the relatively unvarying age of the Juniperus macrocarpa grown in the study area make it distinctively accommodated to address the issue of tree expansion in the arid ecosystems. The climate is recognized as semi-arid continental, mean annual precipitation is close to $750 \mathrm{~mm}$, falling mainly in the winter season. The mean maximum temperature in July of $35.3{ }^{\circ} \mathrm{C}$, while the mean minimum temperature in January of $-3.8{ }^{\circ} \mathrm{C}$, with the Mean annual temperature of $18{ }^{\circ} \mathrm{C}$. Soils are loamy clay which is covered mostly by pastoral forest areas of maquis vegetation (Christodoulakis, 1996; Georghiou and Delipetrou, 2010).

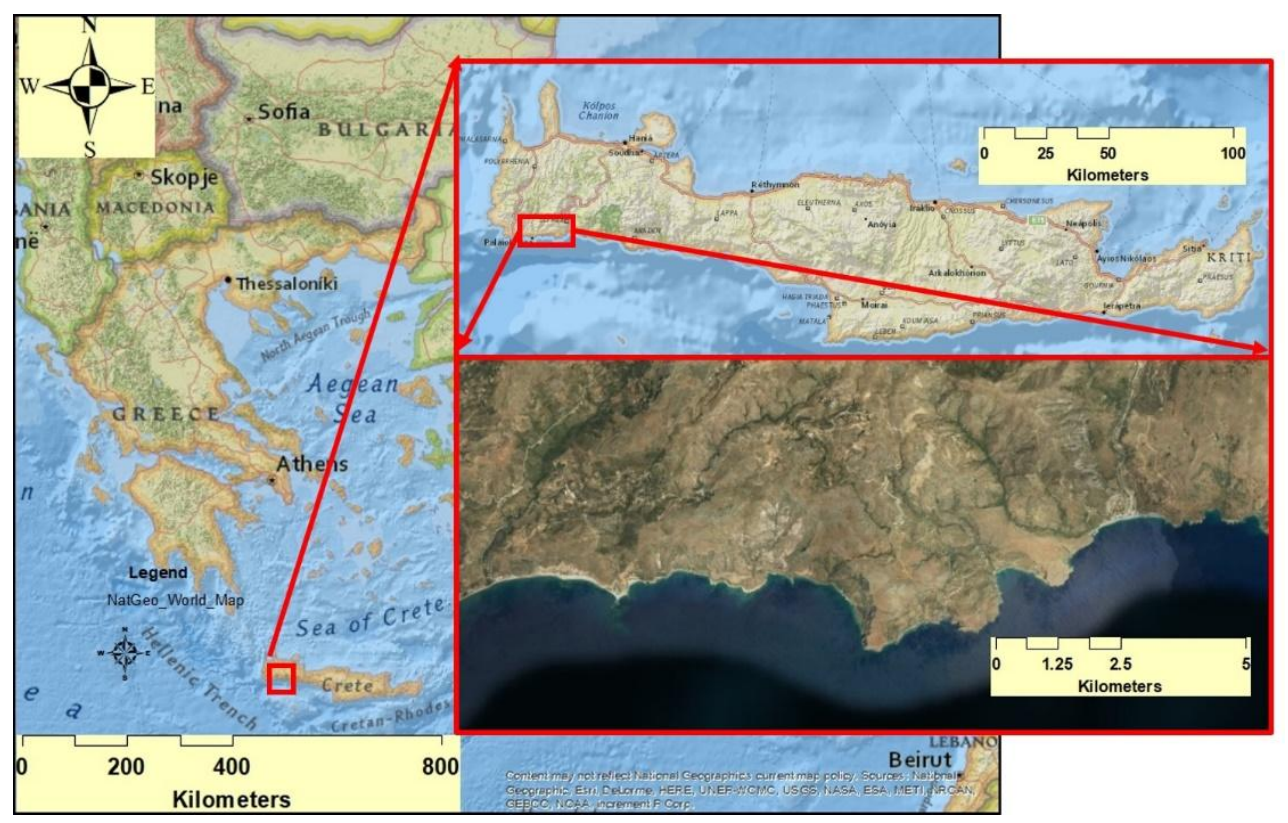

Figure 1. Location of the study area

\section{Experimental design}

The site selected for the study is a stand of J. macrocarpa with a dense canopy. The stand is characterized by slope gradient of $27{ }^{\circ} \mathrm{C}$ and slope aspect of West with slope position of West to Southwest. A $50-\mathrm{m} \times 50-\mathrm{m}$ area was fenced and basic inventory measurements were conducted. Tree density was recorded as 520 trees ha ${ }^{-1}$. Moreover, 22 trees were selected for sap flow measurement. All the trees were even-aged around 40 years old. Three different classes were selected based on the canopy and growth of the trees (Hegazy and Elhag, 2006). The range of the tree height and the diameter at breast height $(\mathrm{DBH})$ for each class is demonstrated in Table 1. Soil moisture determination was carried out using ML2 Theta Probe installed at a different soil depth 
of 20, 40 and $60 \mathrm{~cm}$, respectively. Collected data stored in 15 seconds interval using CR10X, Campbell Scientific Inc., UT data logger.

Table 1. The tree DBH and the tree height range from the selected stand

\begin{tabular}{c|c|c|c|c|c|c}
\hline \multirow{2}{*}{ Tree classes } & \multicolumn{3}{|c|}{ Tree DBH (cm) } & \multicolumn{3}{c}{ Tree height (m) } \\
\cline { 2 - 7 } & Max. & Min. & Avg. & Max. & Min. & Avg. \\
\hline Dominant & 18.74 & 16.14 & 17.44 & 9.09 & 7.89 & 8.49 \\
Co-dominant & 14.35 & 11.35 & 12.85 & 7.66 & 6.26 & 6.96 \\
Suppressed & 10.2 & 6.8 & 8.5 & 5.9 & 4.3 & 5.1 \\
\hline
\end{tabular}

\section{Sap flow and sapwood measurements}

The quantification of the J. macrocarpa transpiration rate was carried out following Granier (1987). Based on the heat differences between the heated probe (implanted in the tree trunk) and the referenced probe $(2 \mathrm{~cm}$ apart) at time $t$ the temperature difference $\Delta \mathrm{T}_{\mathrm{M}}\left({ }^{\circ} \mathrm{C}\right)$ were constantly recorded for sap flux estimation. Based on the experiential association of Granier (1987), the density of the sap flux was conducted in term of Js, $g$ $\mathrm{m}^{-2} \mathrm{~s}^{-1}$ as follows $(E q .1)$ :

$$
I_{s}=119\left(\frac{\Delta T_{M}-\Delta T}{\Delta T}\right)^{1.231}
$$

Clearwater et al. (1999) suggested an empirical correction for sap flux estimation when the sap wood depth is less than $2 \mathrm{~cm}(E q .2)$ :

$$
I_{s}=119\left(\frac{\Delta T_{M}-\frac{\Delta T-b \Delta T_{M}}{a}}{\frac{\Delta T-b \Delta T_{M}}{a}}\right)^{1.231}
$$

where

$a$ is the probe proportion in sapwood

$b$ is the probe proportion in the heartwood, where $b=1-a$.

Transpiration rates determination in term of $\left(\mathrm{L} \mathrm{day}^{-1}\right)$ was conducted as a multiplication of the sapwood area by $J_{s}$. Annual transpiration rate of $J$. macrocarpa canopies in terms of $\left(E_{c}, \mathrm{~mm} \mathrm{yr}^{-1}\right)$ was conducted by multiplying $J_{s}$ with sapwood area $\left(A_{s}\right)$ per unit ground area $\left(A_{G}\right)$ following Oren et al. $(1998 ; E q .3)$ :

$$
E_{c}=J_{s} \frac{A_{g}}{A_{G}}
$$

The determination of the evaporative fraction is based on the energy balance conducted from meteorological stations (Su et al., 2001; Elhag, 2016). Consequently, the net radiation " $R n$ " is estimated by Equation 4:

$$
R n=G 0+H+\lambda \cdot E
$$

where

$R n$ is net radiation (watt $/ \mathrm{m}^{2}$ ), 
$G 0$ is soil heat flux $\left(\mathrm{watt} / \mathrm{m}^{2}\right)$,

$H$ is turbulent heat flux $\left(\right.$ watt $\left./ \mathrm{m}^{2}\right)$,

$\lambda E \quad$ is turbulent latent heat flux (watt $\left./ \mathrm{m}^{2}\right)$,

$\lambda$ is latent heat of vaporization (watt $\left./ \mathrm{m}^{2}\right)$, and

$E \quad$ is actual evaporation (mm/day).

Therefore, the daily evapotranspiration Edaily is exercised following Elhag and Bahrawi (2017b) as (Eq. 5):

$$
\text { Edaily }=\Lambda_{0}^{24} x 8.64 \times 10^{7} \times \frac{R n-G 0}{\lambda \rho \omega}
$$

where
$\bigwedge_{0}^{24}$ is daily evaporative fraction
$\rho_{\omega} \quad$ density of water measured in kilograms per cubic meter.

\section{Statistical analysis}

Initially, a various relapse approach was utilized where every single ecological variable was plotted in a stepwise and covariates relapse. The choice strategy preutilized to distinguish the factors which clarified the main changeability in sap stream. The various relapse approaches were first performed on the whole informational index and afterward performed inside each season. Second, a blended model investigation was consequently performed where the trees were plotted as an irregular impact taking into consideration the changes in the covariance structure. The model was kept running on the general information at to start with, at that point taking a gander at singular months lastly at various seasons.

\section{Results}

Trends in air temperature were reliable with the archived metrological data (22-year average), with the maximum temperature recorded in August $\left(>32^{\circ} \mathrm{C}\right)$, and minimum temperature recorded in January $\left(<-6{ }^{\circ} \mathrm{C}\right)$. Recorded precipitation data in 2011 was significantly exceeding the average $(780 \mathrm{~mm})$, while that of 2012 was average (590 $\mathrm{mm})$.

The seasonal soil volumetric water content was highly variable at the $20 \mathrm{~cm}$ depth, reflecting recent precipitation events. In contrast, the water content at the 40 and $60 \mathrm{~cm}$ depths was less responsive to precipitation events. The site received a total of $229.8 \mathrm{mmol} \mathrm{m}^{-2} \mathrm{~s}^{-1}$ of photosynthetically active radiation in 2011 and $213.9 \mathrm{mmol} \mathrm{m}^{-2} \mathrm{~s}^{-1}$ in 2012. The cloudier days observed throughout the growing spell of 2012 could be recognized as a lower Photosynthetically Active Radiation (PAR) in 2012 relative to 2011 as is shown in Figure 2.

Annual transpiration trends were generally bell-shaped (Fig. 3). Transpiration rates varied significantly between seasons represented as Day of the Year (DOY). Maximum transpiration rates were observed during the growing season with an average of 134.42 $\mathrm{Ld}^{-1}$ for dominant trees and $8.68 \mathrm{Ld}^{-1}$ for suppressed ones. The highest daily rates for the largest tree measured was more than 30-fold that of the smallest tree. This was probably a result of the greater leaf area (green canopy), vigor, and exposure to radiation in larger trees relative to the suppressed ones (Tables 2 and 3). 

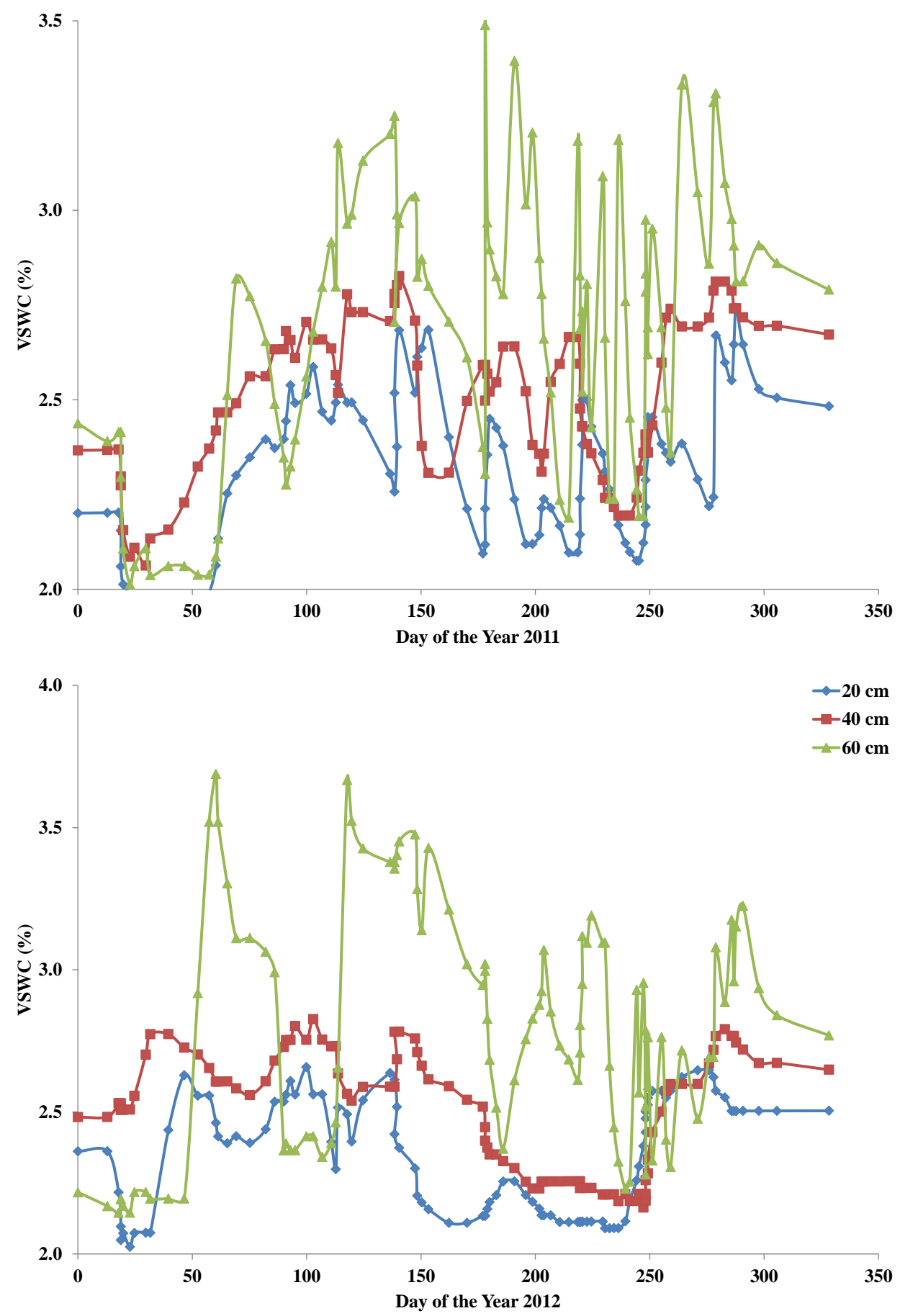

Figure 2. The daily average of soil volumetric water content (VSWC) in different depths

Table 2. Descriptive data of sap flow in L day

\begin{tabular}{c|c|c}
\hline Season & Mean & Std. error \\
\hline Winter & $1.46 \mathrm{~d}$ & 0.10 \\
Spring & $3.32 \mathrm{~cd}$ & 0.20 \\
Summer & $16.62 \mathrm{a}$ & 0.31 \\
Autumn & $10.77 \mathrm{~b}$ & 0.43 \\
\hline
\end{tabular}


Table 3. Tree class description in the designated study area

\begin{tabular}{c|c|c|c|c}
\hline Canopy class & Average DBH $(\mathbf{c m})$ & $\begin{array}{c}\text { Average tree } \\
\text { height }(\mathbf{m})\end{array}$ & $\begin{array}{c}\text { Average height of } \\
\text { life branches from } \\
\text { the ground }(\mathbf{m})\end{array}$ & $\begin{array}{c}\text { Average green } \\
\text { canopy }(\%)\end{array}$ \\
\hline Dominant & 17.44 & 8.49 & 1.91 & 75.51 \\
Co-dominant & 12.85 & 6.96 & 1.78 & 73.68 \\
Suppressed & 8.5 & 5.1 & 3.2 & 10.57 \\
\hline
\end{tabular}

The fall season commenced at the beginning of September and ended in November. The fall was characterized by wet conditions, accompanied by a sharp decrease in PAR and air temperatures, and the resulting transpiration rates (Fig. 3).

With the onset of the spring season, the average daily air temperatures increased from $12{ }^{\circ} \mathrm{C}$ to $26.3{ }^{\circ} \mathrm{C}$ (in both years), and light levels increased significantly from $119 \mu \mathrm{mol} \mathrm{m} \mathrm{s}^{-2}$ to $1298 \mu \mathrm{mol} \mathrm{m} \mathrm{s}^{-1}$ in 2011 and $50.9 \mu \mathrm{mol} \mathrm{m} \mathrm{s}^{-1}$ to $1301 \mu \mathrm{mol} \mathrm{m} \mathrm{s}^{-1}$ in 2012. These higher PAR levels and warmer temperatures, in conjunction with increased cell and photosynthetic activities, resulted in increased transpiration rates. The transpiration rate increased from $1.55 \pm 0.08 \mathrm{Ld}^{-1}$ in the winter period to $3.29 \pm 0.15 \mathrm{Ld}^{-1}$ in the spring, irrespective of tree canopy class.

Variations in air temperature and light levels were shown to have the greatest influence on the transpiration of $J$. macrocarpa. Soil water content limitation varied with depth and depended on the season. Figure 4 shows the daily maximum and average sap flow in correspondence to the minimum and maximum air temperatures.

Sap flow tendencies were commonly plotted as bell-shaped curves over the daily sampling time of $24 \mathrm{~h}$, with the peak sap flow occurring near noon in spring and summer and around $1400 \mathrm{~h}$ in the fall. Significant diurnal variability in sap flow rates was observed and was related to variations in air temperature. In the fall, sap flow for dominant, co-dominant and suppressed trees increased from 0800 to $1400 \mathrm{~h}$, peaked just after $1400 \mathrm{~h}$ and then began decreasing after $1600 \mathrm{~h}$ (Fig. 5).

Table 4 indicates that photosynthetic active radiation, precipitation, and VPD had the greatest influence on the transpiration rates of Juniperus macrocarpa. Analysis of variance for the measured environmental factors influencing tree transpiration rates is presented in Table 4. On an annual basis, all measured environmental parameters had significant impacts on tree level transpiration rates with the exception of volumetric soil water content at 40 and $60 \mathrm{~cm}$ depths, which were expected since water was not a limiting factor in 2011 and 2012. To understand the relative importance of a specific environmental parameter to the seasonal trend of tree-level transpiration rates, the data were grouped into four seasons.

In winter, which included December through to the end of February, least and mean air temperatures, rainfall, photosynthetic active radiation, average relative humidity, and deep soil water $(60 \mathrm{~cm})$ had a significant effect on the transpiration of the trees (Table 4). Air temperatures fluctuated between $3.2{ }^{\circ} \mathrm{C}$ (min temperature) and $16.8{ }^{\circ} \mathrm{C}$ (max temperature) during this period, and positive transpiration rates were observed at air temperatures greater than $14{ }^{\circ} \mathrm{C}$.

The summer season started in May and ended in August. Daily average air temperatures and PAR reached their maximum of around $40{ }^{\circ} \mathrm{C}$ and $1488 \mu \mathrm{mol} \mathrm{m}^{-2} \mathrm{~s}^{-1}$ in 2011 and $30^{\circ} \mathrm{C}$ and $1398 \mu \mathrm{mol} \mathrm{m}^{-2} \mathrm{~s}^{-1}$ in 2012. 

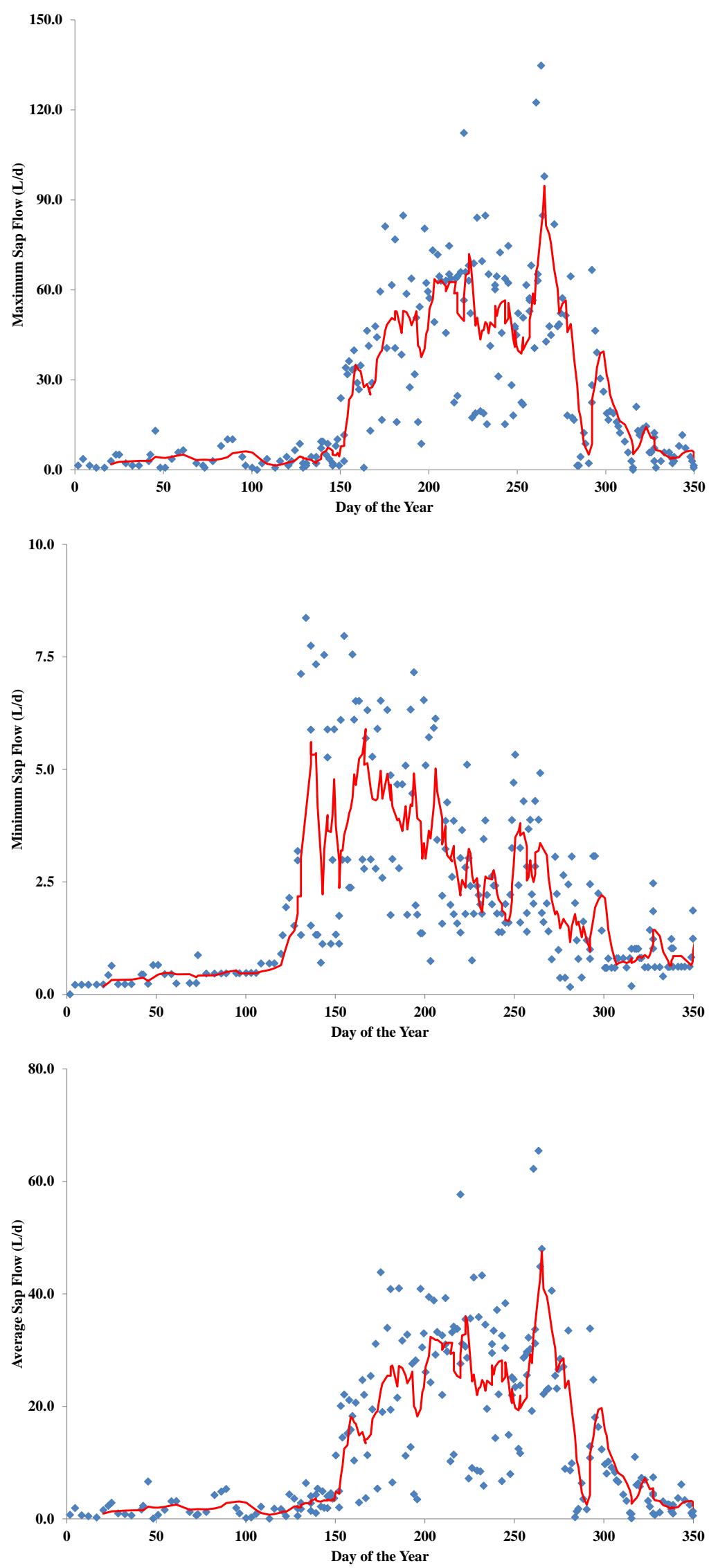

Figure 3. Maximum, mean and minimum sap flow recorded for evenly aged J. macrocarpa 

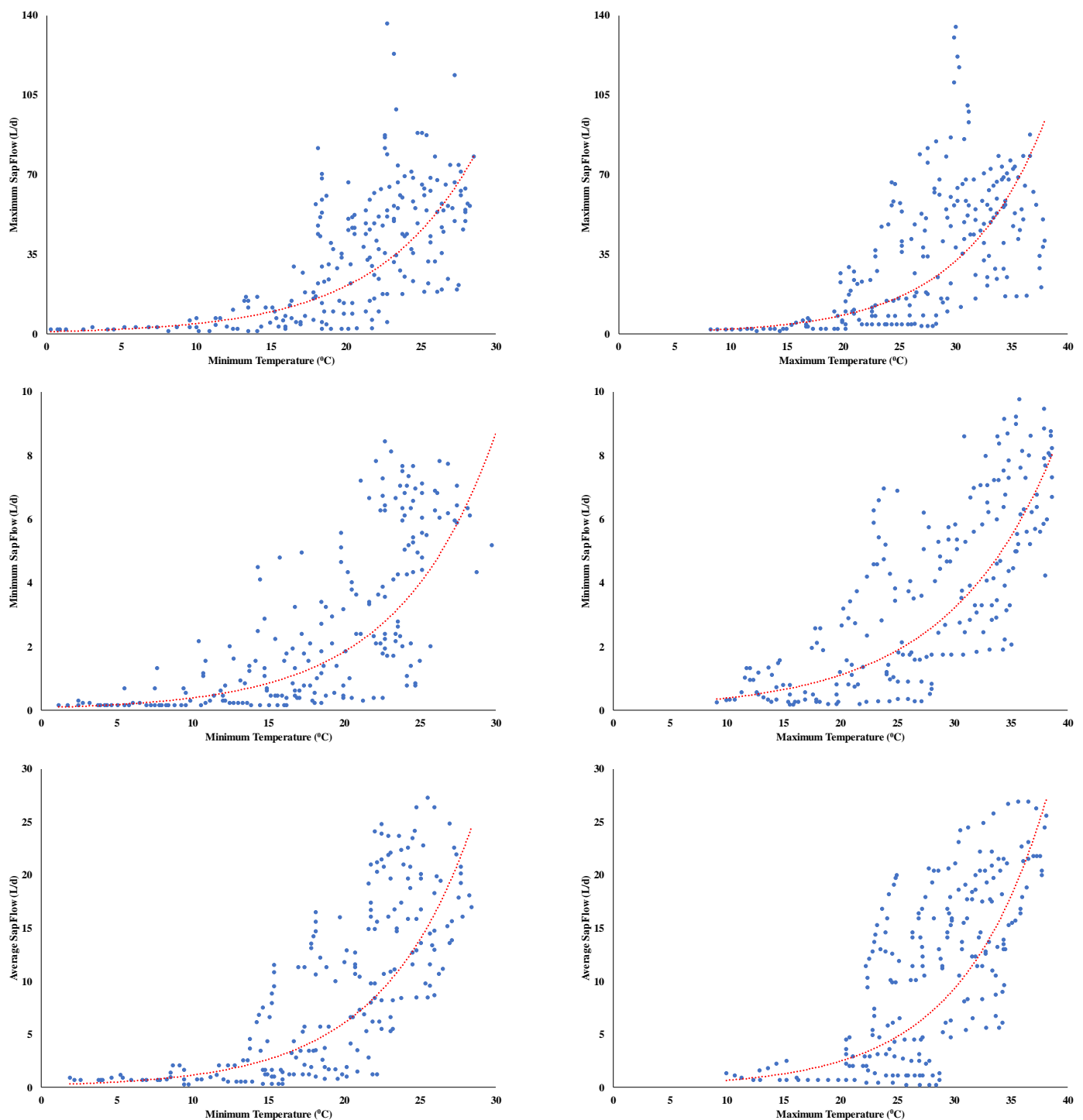

Figure 4. Daily sap flow behavior as a function of minimum air temperature (TA min) and maximum air temperature (TA max) within the designated study area

Daily, whole-tree transpiration (sap flow estimations) reacted significantly to the sunlight. Daytime sap flow as a rainfall and soil water content function was not substantial. However, within-day variability is highly connected to light levels (PAR). Figure 5 shows how sensitive the flow to sudden changes is in light (example: a cloud passing). When PAR showed an increase, or decrease, the sap flow increased or decreased instantly.

\section{Discussion}

The values obtained are comparable to the water use values measured on other Juniperus sp. (Table 1). Transpiration rates of Juniperus macrocarpa trees in the designated study area varied among canopy classes, with highest values observed in the dominant canopy, followed by the co-dominant and finally the suppressed canopy. This 
is in covenant with the outcomes of Granier et al. (1996), Andrade et al. (1998) and Meinzer et al. (2001), who reported that canopy status (dominant, co-dominant, and suppressed) is the key feature defining sap flow rates. According to Lassoie et al. (1983), photosynthetically active radiation is the most important environmental factor regulating photosynthesis in understory eastern red cedar. Hence, transpiration in understory eastern red cedar (for the suppressed stands) is in great part light-limited throughout the 5-month period when fully expanded overstory leaves are present.

Table 4. Rehashed measure examinations of fluctuation by year, season and month for sap stream as a component of every day mean temperature $\left({ }^{\circ} \mathrm{C}\right)$, vapor pressure deficit $(V P D)$, photosynthetic active radiation $(P A R)$, precipitation $(\mathrm{mm})$, daily average soil temperature $\left({ }^{\circ} \mathrm{C}\right)$ and diameter at breast height $(\mathrm{DBH})$

\begin{tabular}{|c|c|c|c|c|c|c|c|}
\hline & $\begin{array}{c}\text { Air Temp. } \\
\left({ }^{\circ} \mathrm{C}\right)\end{array}$ & $\begin{array}{l}\text { VPD } \\
(\mathrm{kPa})\end{array}$ & \begin{tabular}{cc|} 
PAR \\
$\left(\mathrm{mmol} \mathrm{m}^{-2} \mathrm{~s}^{-1}\right)$ \\
\end{tabular} & $\begin{array}{c}\text { Precip. } \\
\text { (mm) }\end{array}$ & $\begin{array}{c}\text { SM Temp. } \\
\left({ }^{\circ} \mathrm{C}\right)\end{array}$ & DBH (cm) \\
\hline Year & 2011/2012 & $* * *$ & $* * *$ & $* *$ & $* * *$ & $* * *$ & $*$ \\
\hline \multirow{4}{*}{ Season } & Summer & $* * *$ & $*$ & $* *$ & - & - & $*$ \\
\hline & Fall & - & - & * & $* *$ & - & $*$ \\
\hline & Winter & $*$ & - & $*$ & $* *$ & - & - \\
\hline & Spring & $*$ & $*$ & $*$ & $* *$ & - & - \\
\hline \multirow{12}{*}{ Month } & August & $* *$ & - & * & $*$ & - & $*$ \\
\hline & September & - & - & $*$ & - & - & $*$ \\
\hline & October & $*$ & $*$ & $*$ & - & - & - \\
\hline & November & - & - & - & - & - & - \\
\hline & December & - & - & - & - & $* * *$ & - \\
\hline & January & * & - & * & $*$ & - & - \\
\hline & February & - & - & - & $* * *$ & - & - \\
\hline & March & - & - & * & * & - & - \\
\hline & April & $*$ & - & - & $* *$ & - & - \\
\hline & May & - & - & - & - & $*$ & - \\
\hline & June & $*$ & - & - & $* *$ & $*$ & $*$ \\
\hline & July & - & - & $* * *$ & - & - & $*$ \\
\hline
\end{tabular}

Only significant interactions are displayed

Transpiration declined in fall and winter but continued progressive when temperatures were $>0{ }^{\circ} \mathrm{C}$. Results were in agreement to those observed by Briggs et al. (2002) and explained by the fact that Juniperus macrocarpa trees maintain positive photosynthesis and stomatal conductance at temperatures above $0{ }^{\circ} \mathrm{C}$ and they efficiently utilize water from the deeper rescinded soil horizons (Brümmer et al., 2012). This might contribute to the accumulation of biomass and might result in decreased soil water content, which otherwise will be used to recharge the groundwater in grasslanddominated areas. Transpiration rates increased with the improvement in weather conditions, reaching their maximum during the growing season. The absence of a drought period during our study (2011-2012) did not show the response of Juniperus macrocarpa to drought stress. 

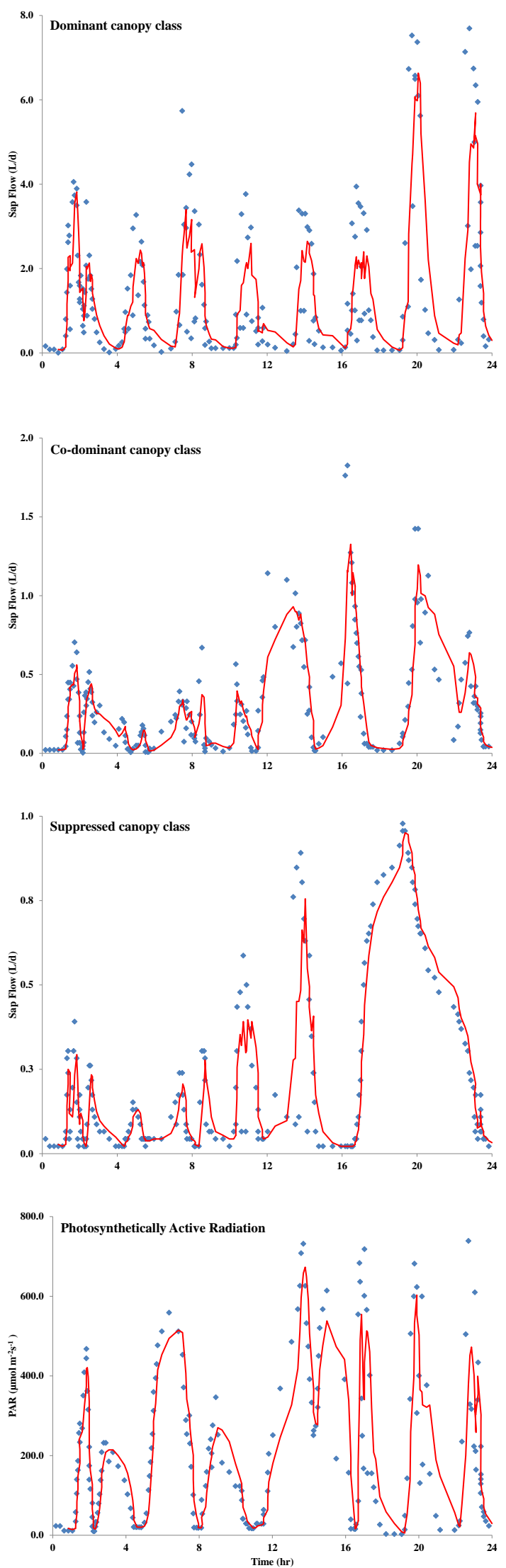

Figure 5. The daily curves of Sap flow $\left(L h^{-1}\right)$ and PAR for the three canopy classes of J. macrocarpa 
However, according to Brümmer et al. (2012), even under drought stress, Juniperus macrocarpa has the capacity to preserve stomatal opening at low water potentials, and utilize deeper soil water. The annual transpiration rate per unit ground area $\left(\mathrm{mm} \mathrm{yr}^{-1}\right)$ was estimated for 2011 through scaling up mean flux density by multiplying it by sapwood area per unit ground area (Oren et al., 1998). Results showed that trees utilized on average between 0.18 and $1.79 \mathrm{~mm} \mathrm{~d}^{-1}$ and averaged $376 \mathrm{~mm} \mathrm{yr}^{-1}$, which represented $52 \%$ of the annual precipitation, leading to drier soils under forested cover compared to open grasslands. In winter, fall and early spring, while grasses are dormant, trees were effectively consuming water that otherwise would go to charge the groundwater (Briggs et al., 2002).

Leaf water deficit, transpiration and stomatal opening all reflect increase in soil moisture suction but that, during the day, they are affected also by other factors which obscure the direct effect of soil moisture (Rutter and Sands, 1958). The logistic relation is the competition that limits in some cases the grass-land from maintaining its healthy growth and from another aspect grass-land may limit the expansion of the forests due to the allelopathic effect (Hegazy et al., 2004). Therefore, low soil moisture content has an insignificant role in the trees expansion which is also confirmed by the survival of $J$. macrocarpa in low soil water content (Seim et al., 2016).

\section{Conclusion}

Results indicated that diurnal air temperatures determined the overall stomatal status, whereas inconstant light levels accounted for stomatal activities during the daylight, thus regulating the jeopardy of severe water discrepancies. Transpiration character of the studied species followed the bell-shaped curve with exposure sensitivity. Moreover, the phenological classes of Juniperus macrocarpa did not considerably affect the transpiration character. Soil moisture, while very important, did not seem to limit the expansion of the tree under investigation, unlike what has been observed in the seven years prior to this study. Therefore, this species can continue invading and displace the dominant native grasses and potentially affect the groundwater recharge as well as the surrounding grassland. In conclusion, appropriate management must be designed to control Juniperus macrocarpa expansion, and more realistic and attainable goals and management regimes for the current site conditions should be adopted to minimize the impacts of this continuous invasion of Juniperus macrocarpa on long-term ecosystem processes especially the surrounding grassland and services including groundwater.

Acknowledgement. This work was supported by the Deanship of Scientific Research (DSR) at King Abdulaziz University, Jeddah, under grant No. (114-155-1438D). The authors, therefore, gratefully acknowledge the DSR technical and financial support.

\section{REFERENCES}

[1] Adams, R. P. (2014): Junipers of the World: The Genus Juniperus. - Trafford Publishing, Bloomington.

[2] Andrade, J. L., Meinzer, F. C., Goldstein, G., Holbrook, N. M., Cavelier, J., Jackson, P., Silvera, K. (1998): Regulation of water flux through trunks, branches, and leaves in trees of a lowland tropical forest. - Oecologia 115: 463-71. 
[3] Bradley, B. A., Fleishman, E. (2008): Relationships between expanding pinyon-juniper cover and topography in the central Great Basin, Nevada. - Journal of Biogeography 35: 951-64.

[4] Briggs, J. M., Knapp, A. K., Brock, B. L. (2002): Expansion of woody plants in tallgrass prairie: a fifteen-year study of fire and fire-grazing interactions. - The American Midland Naturalist 147: 287-94.

[5] Briggs, J. M., Schaafsma, H., Trenkov, D. (2007): Woody vegetation expansion in a desert grassland: Prehistoric human impact? - Journal of arid environments 69: 458-72.

[6] Brümmer, C., Black, T. A., Jassal, R. S., Grant, N. J., Spittlehouse, D. L., Chen, B., Nesic, Z., Amiro, B. D., Arain, M. A., Barr, A. G. (2012): How climate and vegetation type influence evapotranspiration and water use efficiency in Canadian forest, peatland and grassland ecosystems. - Agricultural and Forest Meteorology 153: 14-30.

[7] Chaves, M. M., Maroco, J. P., Pereira, J. S. (2003): Understanding plant responses to drought - from genes to the whole plant. - Functional Plant Biology 30: 239-64.

[8] Christodoulakis, D. (1996): The phytogeographical distribution patterns of the flora of Ikaria (E Aegean, Greece) within the E Mediterranean. - Flora 191: 393-99.

[9] Clearwater, M. J., Meinzer, F. C., Andrade, J. L., Goldstein, G., Holbrook, N. M. (1999): Potential errors in measurement of nonuniform sap flow using heat dissipation probes. Tree Physiology 19: 681-87.

[10] Darrouzet-Nardi, A., D'Antonio, C. M., Dawson, T. E. (2006): Depth of water acquisition by invading shrubs and resident herbs in a Sierra Nevada meadow. - Plant and Soil 285: $31-43$.

[11] Duursma, R. A., Kolari, P., Perämäki, M., Nikinmaa, E., Hari, P., Delzon, S., Loustau, D., Ilvesniemi, H., Pumpanen, J., Mäkelä, A. (2008): Predicting the decline in daily maximum transpiration rate of two pine stands during drought based on constant minimum leaf water potential and plant hydraulic conductance. - Tree Physiology 28: 265-76.

[12] Elhag, M. (2016): Inconsistencies of SEBS model output based on the model inputs: Global sensitivity contemplations. - Journal of the Indian Society of Remote Sensing 44: 435-42.

[13] Elhag, M., Bahrawi, J. (2016): Deliberation of hilly areas for water harvesting application in western Crete, Greece. - Global Nest Journal 18: 621-29.

[14] Elhag, M., Bahrawi, J. A. (2017a): Consideration of Soil Water Consumption of Juniperus Macrocarpa in Semi-Arid Ecosystem in Western Crete, Greece, pp. 1-6. - 15th International Conference on Environmental Science and Technology, Rhodes, Greece.

[15] Elhag, M., Bahrawi, J. A. (2017b): Realization of daily evapotranspiration in arid ecosystems based on remote sensing techniques. - Geoscientific Instrumentation, Methods and Data Systems 6: 141.

[16] Farjon, A. (2005): A Monograph of Cupressaceae and Sciadopitys. - Royal Botanic Gardens, Kew, Richmond, Surrey, UK.

[17] Fredrickson, E. L., Estell, R., Laliberte, A., Anderson, D. (2006): Mesquite recruitment in the Chihuahuan Desert: historic and prehistoric patterns with long-term impacts. Journal of Arid Environments 65: 285-95.

[18] Georghiou, K., Delipetrou, P. (2010): Patterns and traits of the endemic plants of Greece. - Botanical Journal of the Linnean Society 162: 130-422.

[19] Granier, A. (1987): Evaluation of transpiration in a Douglas-fir stand by means of sap flow measurements. - Tree Physiology 3: 309-20.

[20] Granier, A., Huc, R., Barigah, S. (1996): Transpiration of natural rain forest and its dependence on climatic factors. - Agricultural and Forest Meteorology 78: 19-29.

[21] Harmsen, E. W., Miller, N. L., Schlegel, N. J., Gonzalez, J. (2009): Seasonal climate change impacts on evapotranspiration, precipitation deficit and crop yield in Puerto Rico. - Agricultural Water Management 96: 1085-95. 
[22] Hegazy, A., Elhag, M. (2006): Considerations of demography and life table analysis for conservation of Acacia tortilis in South Sinai. - World Applied Sciences Journal 1: 97106.

[23] Hegazy, A., Fahmy, G., Ali, M., Gomaa, N. (2004): Vegetation diversity in natural and agro-ecosystems of arid lands. - Community Ecology 5: 163-76.

[24] Heilman, J., Mcinnes, K., Kjelgaard, J., Owens, M. K., Schwinning, S. (2009): Energy balance and water use in a subtropical karst woodland on the Edwards Plateau, Texas. Journal of Hydrology 373: 426-35.

[25] Lassoie, J. P., Dougherty, P. M., Reich, P. B., Hinckley, T. M., Metcalf, C. M., Dina, S. J. (1983): Ecophysiological investigations of understory eastern redcedar in central Missouri. - Ecology 64: 1355-66.

[26] Lu, P., Müller, W. J., Chacko, E. K. (2000): Spatial variations in xylem sap flux density in the trunk of orchard-grown, mature mango trees under changing soil water conditions. - Tree Physiology 20: 683-92.

[27] Meinzer, F., Goldstein, G., Andrade, J. (2001): Regulation of water flux through tropical forest canopy trees: do universal rules apply? - Tree Physiology 21: 19-26.

[28] Muñoz-Reinoso, J. C. (2004): Diversity of maritime juniper woodlands. - Forest Ecology and Management 192: 267-76.

[29] Oren, R., Ewers, B. E., Todd, P., Phillips, N., Katul, G. (1998): Water balance delineates the soil layer in which moisture affects canopy conductance. - Ecological Applications 8: 990-1002.

[30] Owens, K., Ansley, J. (1997): Ecophysiology and Growth of Ashe and Redberry Juniper. Juniper Symposium, pp. 19-31. - Texas A\&M University, San Angelo, TX.

[31] Owens, M. K., Lyons, R. K., Alejandro, C. L. (2006): Rainfall partitioning within semiarid juniper communities: effects of event size and canopy cover. - Hydrological Processes 20: 3179-89.

[32] Porporato, A., Daly, E., Rodriguez-Iturbe, I. (2004): Soil water balance and ecosystem response to climate change. - The American Naturalist 164: 625-32.

[33] Rutter, A., Sands, K. (1958): The relation of leaf water deficit to soil moisture tension in Pinus sylvestris L. - New Phytologist 57: 50-65.

[34] Seim, A., Tulyaganov, T., Omurova, G., Nikolyai, L., Botman, E., Linderholm, H. W. (2016): Dendroclimatological potential of three juniper species from the Turkestan range, northwestern Pamir-Alay Mountains, Uzbekistan. - Trees 30: 733-48.

[35] Stocker, T. (2014): Climate Change (2013): The Physical Science Basis. Working Group I Contribution to the Fifth Assessment Report of the Intergovernmental Panel on Climate Change. - Cambridge University Press, Cambridge.

[36] Su, Z., Schmugge, T., Kustas, W., Massman, W. (2001): An evaluation of two models for estimation of the roughness height for heat transfer between the land surface and the atmosphere. - Journal of Applied Meteorology 40: 1933-51.

[37] Thurow, T. L., Hester, J. W. (1997): How an Increase or Reduction in Juniper Cover Alters Rangeland Hydrology. Juniper Symposium Proceedings, pp. 9-22. - Texas A\&M University, San Angelo, Texas, USA.

[38] Van Auken, O. (2000): Characteristics of intercanopy bare patches in Juniperus woodlands of the southern Edwards Plateau, Texas. - The Southwestern Naturalist 45(2): 95-110.

[39] Van Auken, O., Mckinley, D. C. (2008): Structure and Composition of Juniperus Communities and Factors That Control Them. Western North American Juniperus Communities. - Springer, New York.

[40] Van Haverbeke, D. F., Read, R. A. (1976): Genetics of Eastern Redcedar. - Forest Service Research Paper WO-32. USDA, Washington. 